\title{
The role of agency theory in the relationship between foreign ownership and performance-risk of stock in Indonesia: is one or two-way interaction?
}

\author{
Ahmad Maulin Naufa ${ }^{1}$ and I Wayan Nuka Lantara1 \\ ${ }^{1}$ Department of Management, Faculty of Economics and Business, Universitas Gadjah Mada, Indonesia
}

\begin{tabular}{ll}
\hline Abstract & Using agency theory as a theoretical basis, this paper aims to examine the relationship \\
between foreign ownership, performance, and risk. Particularly, we examine whether the \\
foreign ownership can improve or reduce the performance and risk. Vice versa, it also \\
examine whether performance and risk may also influence the foreign ownership of stock. \\
We utilized samples from the 100 Kompas Index from the Indonesian Stock Exchange \\
(IDX), and we obtained 87 stocks from 2011-2017. We analyzed the relationship using \\
ordinary least square by EViews 10.0. The result shows that the foreign ownership \\
contributes positively to the improvement of performance, although the performance does \\
not affect significantly to foreign ownership. Then, the relationship between the foreign \\
ownership and the risk are not significant. The relationship the risk to the foreign is also \\
not significant. To commence with, the foreign has an essential role in the improvement of \\
Indonesian stock performance.
\end{tabular}

\section{INTRODUCTION}

Stock is one of the financial instruments in many countries including Indonesia. By cutting-edge of technology especially in the industrial revolution 4.0 era, Indonesian stock not only can be owned by the domestic investors but also the foreign investors. Some people believe that foreign investors can provide some benefits i.e. their control, transparency, technology transfer, risk sharing, and good corporate governance to a company based on the corporate governance theory (Shleifer and Vishmy, 1997; Becht et al. 2003).

On the contrary, some other researchers argue that they give loss or negative contributions to the stock, because the stock owned by the foreign not inevitably lower risk, nevertheless the risk can be higher. The foreign ownership has a negative impact to the performance and risk which can be explained by the agency theory (Jensen and Meckeling, 1976), whereas there is a possible conflict between foreign and domestic investor that can make an inefficiency, especially the conflict of interest between foreign and domestic owners who have different preference on the risk.On one side, the foreign might be the risk taker, while on another side, the domestic owners are risk-averse. That different preference toward the risk would lead the conflict among those investors. That conflict would provide to the poor stock performance. In another hand, some found that there is no interaction between foreign ownership to the stock's performance and risk (Bekaert and Harvey, 1997; De Santis and Imrohoroglu, 1994; Kim and Singal, 2000).

The main ideas of this research consist of two points: 1) how the relationship of foreign ownership to the performance and risk of the stock. Whether by the stock is owned by the foreign investor, the performance and risk could be better or worse. 2). The better performance of stock may attract foreign investor to enter. These conditions would make the foreign investor attaining gain/profit. The lower risk may also become interesting for the foreigners, whereas it can provide a safe investment opportunity for them. The higher the risk the higher the return. We would explore more which one the earlier influence, those reasons above provide both foreign to risk-performance and riskperformance to foreign could be influenced by each other. 
This phenomenon also can be explained by the other theories like ownership structure foreign subsidiaries (Gomes, 1989), transaction cost (Williamson, 1981), institutional (Di Magio and Powell, 1983), and agency theory (Jensen and Mckeling, 1976), but we choose to focus on the agency theory. According to Jensen and Mckeling (1976), an agency conflict can occur between the manager and the owner, also between the majority and minority shareholders. That conflict also can be happened due to the separation between the company's ownership and control. In addition, Kurniawati and Komalasari (2014) suggested that conflict also exists between state ownership and foreign ownership, the Indonesian government as state representative who is risk averse, while the foreign owner is risk taker both individual and institutional because they have ability, knowledge, and developed technology to make the company more enlarging by expansion. Foreign ownership is defined by entirelyor majority owned the business or resource in the country by an individual or company who is not the citizen of that country. It happened from multinational activity, longterm investment (foreign direct investment), and subsidiary.

In Indonesia, the government has ever limited the foreign investors in some sector like a plantation to protect the small local plantation company until 30\%. In another country like Qatar also has limitation to foreign ownership is from $49 \%$ to be strictly $25 \%$, it helps to select the only long-term investor who may enter. Lastly, Russia limits it by no more than $25 \%$.

Those attract us to explore deeply the literature on how the relationship between foreign ownership and risk-performance is. Whether that relationship is only one direction or it can be two way from the agency theory view. Much literature has conducted on the relationship between foreign ownership and performance, and foreign direct investment (FDI), but in the two-way relationship, e.g. performance-risk to foreign ownership is quite limited. Based on those problem backgrounds, we attempt to examine whether foreign ownership influences performance and risk. We also test whether stock performance and risk influences foreign ownership.

\section{LITERATURE REVIEW AND HYPOTHESES DEVELOPMENT}

Since 2000s, there has been an increase in foreign investors in many developing countries as a result of financial liberalization and globalization. The disappearing of investment limit among countries makes it easy to do. In many developing countries, international investment becomes the source of economic growth (Vo, 2015).

According to Phung and Mishra (2015), the percentage of foreign ownership is the percentage of the stock owned by foreign both individual or institutional. The goal of the stock owner is commonly to maximize their wealth, nevertheless by the time their purpose can be different: 1) to improve job opportunity (society) 2) To prevent the penetration of foreign investors and protect domestic investors (politic) (Phung and Misrha, 2015).

According to Elliot and Zhou (2015), foreign investors may play an important role inthe stockmarket of developing countries. Jiang and Kim (2004), one of its roles is their better ability to process the provided information from the public than domestic investors. Some other studies (De Santis and Imrohoroglu, 1994; Bekaert and Harvey, 1997; and Kim and Singal, 2000) depict that the market openness to foreign investors leads to the proper stability and lower volatility. Grinbalt and Keloharju (2000) added foreign investors, tended to buy winner stocks and sell loser shares. Foreign investors tended to invest in shares which are well performed. Hence, they prefer to choose a large company with a higher export ratio (Merton, 1987).

Nonetheless, they also will face some risk to buy or invest stock from the foreign capital market in other countries like currency, market fluctuations, some situations (politic, economic, social, liquidity, limited information, law, and market operational (Shapiro, 2006; Azar, 2010). Agarwall et al. (2009) stated that foreign investors are risk-averse than domestic. Kwon et al. (2005) may access different information and risk than domestic. Phung and Mishra (2015), the policymakers necessarily need to encourage foreign ownership. Nevertheless, they must spread it inthe broader company, this can be beneficial for increasing the company performance but avoiding its negative impact. 


\section{Agency theory, foreign ownership, and performance-risk}

The view of the agency theory could explain the relationship between foreign ownership and the performance-risk (Jensen and Mckeling, 1976). The notion is a possible conflict between the principal (the manager) with an agent (the foreign stock owner) due to the conflict of interests. On one side, the manager wants company management far from the risk. Nevertheless, the foreign investors as the stock owner pursuehigh-risk investment to obtain a high return. The owner controlled the manager act. Then, the foreign owner also has the voting right in the corporate decision making (corporate action). That conflict leads the business becoming inefficient if the conflict is low the company performance would be high and the risk would be low. In contrast, if the agency problem is high, the company performance would be worse, and the risk would be significant.

Meanwhile, the presence of good corporate governance could solve that conflict, it could make the manager act following the company's goal and the foreign owner does not expropriate his position to affect the company's decision by his interest. The foreign investors should play a critical role in an improvement of the company performance, e.g. risk sharing, technology transfer, additional capital, transparency, accountability, good control, and the direction of the betterdecision-making process. According to Shleifer and Vishmy (1986) related to the agency theory Jensen and Mckeling (1976), the ownership structure quite influenced its risk-taking, only the controlling shareholders who have the power to affect the corporate decision to maximize the profit by taking the risk, it is equal with a diversification. Fama and Jensen (1983) added the combination of ownership and control could help the concentrated shareholder to change the profit with the private rents. Galais and Masulis (1976) stated the first source conflict between manager and stockholder comes from their different perception about the risk, the shareholders with diversified risk tend to be a risk taker with the expectation to obtain a higher return, nevertheless the manager tends to be risk-averse to save his position and the personal benefit. Fuentelsaz et al. (2000) added, uncertainty is one of the fundamental variables in the agency theory, the risk would increase if the principal and agent have a different attitude toward the risk. At least, one party would be risk-averse, the common assumption is that the principal is neutral and the agent is risk averse.

The decision of shareholders can be positive and negative toward the risk, sometimes they like to take the risk to attain higher profit, and in other times they also can be risk-averse to invest safely. Ross et al. noted that if the percentage of ownership is high (majority), the majority shareholders can determine the corporate structure of whoever can have a particular position in the company. It makes themajority of shareholders having control of the company. Furthermore, Chaganti and Damanpour (1991) and Mintzberg (1983) about the ownership dimension regarding the corporate decision, the shareholders can be involved (involvement) and uninvolved (detachment). The higher involved the owners, and the more concentrated the ownership, the larger the power they should have in influencing the corporation (Chaganti and Damanpour, 1991 p.3).

In the agency theory view, the concentrated ownership would increase the shareholders to monitor the company management, avoid the decision that benefits personally one party and negatively to the company performance. Nonetheless, this argument is right in the law which protects the minority shareholders, if the law is weak or not exists, the company control by the majority shareholders would happen, and it will bring negative impact to the corporation. Albeit, in theory, the separation of ownership and control can be done to provide benefit to the company, but in reality, it is difficult to realize. Not only foreign ownership is hypothesized influencing the performance, but the performance may also influence the foreign investor to enter, the literature commonly focused on the foreign direct investment (FDI), little literature discussed the foreign ownership. The both are different, ownership means owning the shares, however, FDI more than that, it is like entirely build and invest in the company in the foreign countries. Then, the joint venture is one part of FDIs.

In Indonesia, the second conflict that may appear is the conflict between the Indonesian government and foreign ownership. Both may have a different purpose to the company, and the conflict of interest may occur. The government may limit the ownership stock by the foreign because the also bring the global risk and to protect the domestic investor, while the foreign investor may desire to own the 
stock without restriction. If the foreign investors own the stock, they may play in the company decision making. Indonesian company particularly the state-company (Badan Usaha Milik Negara), insurance, and plantation now commonly restricted foreign ownership. If the financial system and regulation in a country well-supports the foreign to enter, it will attract the foreign investor. However, in this globalization era, foreign investors are demanding to limit because the countries need additional capital. At least the government can keep the majority holding (minimum the government owns 51\% percent).

Besides the agency theory can explain foreign ownership phenomenon, other theories of the firm may also explain it like transaction cost theory, Hennart (1988) said that every organization would choose the governance structure which can minimize the total transaction cost, including contract cost, performance monitoring, and monitoring the partner behavior. In this theory, entering foreign ownership may add and or reduce those costs. Then, the efficient market hypothesis by Fama (1970), the theory implied that the market wouldrespond with some new relevant information, whether foreign ownership is relevant or not.

Furthermore, the further is the prospect theory; it explains that the economic decision is a considered choice between benefit and the risk, rather than the result. The loss (risk) has a more significant role than the benefit. In this topic, the risk may make the foreign investors avoid it, while the company performance would attract them to enter. More than that, Phung and Mishra (2015) used multi-perspective theory to explain the foreign ownership phenomenon (agency, resource-based, and institutional) to 1,005 companies in India between 1999-2000, they found that the foreign ownership has the positive effect toward the risk due to involving in the monitoring and governance of company internal. Next, institutional theory from Oliver (1992) in Olcott (2009), some Japanese companies have been taken over by foreign owners, where the routine activity of organization and the foundation value can be delegitimized by them (deinstitutionalization). Barney (1991) explained the resource-based view, in this view the foreign ownership may become the source of competitive advantage that the other companies do not have.
Based on some existing literature, we attempt to summarize it for formulating some hypothesizes which hopefully could answer the research matters. Firstly, despite the relationship of the foreign ownership to the performance is contradictive, we choose to hypothesize that the foreign contributes positively to the performance. Study byPhung and Mishra (2015), foreign ownership can increase the performance of stock due to the fact the foreign investors could give the excellent control and improve the management system, increase the transparency, resource access, technology transfer, risk sharing, learning, productivity, efficiency, and stabilization (Vo, 2015), good corporate governance (Stulz, 1999; Doidge et al. 2004; Becht et al. 2003). It follows the corporate governance from Shleifer and Vishny (1997), where is the good governance, there will occur the company improvement, stimulating the financial industry due to enhancing the network to the capital flow. Jiang and Kim (2004) added the foreign owners have a better ability to process relevant information which is available from the public.

They can enlarge the governance and the quality of opening company investment information (Vo, 2015; Fan and Wong, 2002; Jin and Myers, 2006). De Santis and Imrohoroglu (1994) said the market openness to the foreign investor tends to be more stable and lower volatility. Vein and Melitz (2003) in Ricci and Trionfetti (2012), the new trade theory views that the importance of network to open new market (international trade) positively associates with the foreign network to increase the financial link that would make the company more productive in the future. The foreign ownership enhances the supervision (Fuentelsaz, 2000), monitoring, Liu and Hsu, 2001), knowledge (Peter et al. 2016), liquidity and professional employee, and decrease the agency cost, increase additional capital, return, and long-term commitment (Utama and Musa, 2011). Overall, we believe that foreign can increase performance. Therefore, we take two way hypothesizes as follows:

\section{H1: Foreign ownership positively affects performance of stock in Indonesia}

In the second hypothesis, despite the impact of foreign ownership on the risk is debatable. We believe that foreign shareholders to decrease the risk of stock in 
Indonesia. The foreign ownership plays an important role in the risk sharing (Pambudi and Smyth, 2009; Li et al. 2011) toward the owned stocks so that the risk would be lower (Becht et al. 2003). Entering the foreign investors would contribute to the stock and decrease the risk because the owner can curtail the risk. The owner could tolerate the risk by the preference, taking the correct decision and optimal capital structure (Ang, 2000). Aebi et al. (2012)found any excellent governance and chief risk officer to reduce the risk which is reflected in the higher ROE and return. Wang (2007) proved that foreign ownership alleviates to the company's loss. It suggested that, in our research, the larger stock owned by the foreign investors, the lower risk of stock in Indonesia. Kurniawati and Komalasari (2014), if there is less conflict between the majority and minority shareholders, then the risk of stock would be lower. The separation of control and own could occur (Fama and Jensen, 1983). According to Shleifer and Vishmy (1986) regarding the agency theory that the ownership structure quite influences the risk, the shareholders have a strong incentive and power to influence the company decision toward the risk because it would be equal with the diversification action. The hedging (value protecting) can solve the risk like currency risk (Arfaoui and Rejeb, 2015). Therefore, foreign ownership has a negative impact on the risk of the stock, we composed the hypothesis as follows:

H2: Foreign ownership negatively affects risk of stock in Indonesia.

We suggest that there is also an assumption which the better performance would attract the foreign investors to enter. It makes foreign investors want to obtain gain or profit. Liu Hsu (2014); Khanna and Palepu (1999) in Phung and Mishra (2015) stated that the ultimate goals of the shareholders are to maximize their wealth. If the stocks which they own having good performance, it would provide more massive potential gain than the stocks with poor performance. Vo (2015) added the disappearing of investment limitation among countries made the foreign investors easy to come. Grinbalt and Keloharju (2000), the foreign investors would buy the winner stocks and sell the loser stock, they tend to invest in the stocks with better performance. It is supported by Merton (1987) who stated that they tend to invest in the companies having the higher export ratio. The performance is also hypothesized influencing the foreign investors to invest, like FDI and joint venture (Ferguson, 2005). The Indonesian financial system in the industrial revolution 4.0 and globalization era also supports the foreign ownership to enter; the foreign investors highly own some stocks in Indonesia. Therefore, the performance may influence positively to the foreign ownership. We composed the hypothesis as follows:

H3: Performance positively affects foreign ownership of stock in Indonesia.

The lower risk could attract foreign investors to come because it provides a secure investment to them. If we see from the transaction cost theory, according to Hennart (1988), the organization will choose the governance structure with the lower cost, including the contract, and performance monitoring. If the risk is low, the company has good governance and the potential gain safely, so it attracts the foreign owners to enter.Further, according to the prospect theory ofKahneman and Tversky (1979) on the research about decision making.This theory sees the behavior when the risk occurs. This theory stated that the economic decision is a considered choice between benefit and loss, rather than the result, and the loss has a greater portion than the benefit despite the nominal value is equal. The lower risk means that the stock would be more interesting to own if it compared with the return stock with the same value but the weighted risk is higher. The risk would make the foreign investors afraid to enter even though the performance is equal or highersince the risk has a more significant portion than benefit. Therefore, the risk also may influence negatively toward the foreign ownership (two way hypothesizes), we draw the hypothesis as follows:

H4: the risk negatively affects the foreign ownership of stock in Indonesia.

\section{METHODS}

\section{Data and samples}

We employed market-level analysis here, where it used the analysis on stock population from the Indonesian Stock Exchange (IDX), in particular, the monthly data from the 100 Kompas Index between 2011-2017. The using from an Index is following some previous 
researches like Li et al. (2011) who used the S\&P Index. It helps us to sort more than 500 stocks in the market since the index's stocks have the advantage like the higher liquidity, massive market capitalization, and good fundamental performance. IDX legally launches the 100 Kompas Index in collaboration with Kompas Press on Friday, $10^{\text {th }}$ August 2007. The selected stocks for this index have high liquidity, significant capitalization, good fundamental and performance. Those stocks represent approximately $70-80 \%$ of the total stocks in Indonesia (IDR 1,582 Trillion). Therefore, the investor can attain the movement of all stocks from observing this index.

We employed panel data (combination of time series and cross-section) according to Phung and Mishra (2015) who examined the ownership structure and performance. It depicts the influence of foreign ownership on the performance-risk across the time and the companies. We obtaineddata from some resources like 100 Kompas Index, Yahoo Finance, Custodian Central Depository Effect of Indonesia, Bloomberg, and Osiris. We used a purposive sampling approach; this helps us to take the samples based on specific criteria, where the selected stocks must provide these criteria: 1. Listed at IDX 2. Exist in the 100 Kompas Index from 2011-2017 at least three times 3. The majority variables data are available (unbalanced data). Based on those criteria, we obtained 87 stocks in 7 years (approximately 609 observations).

\section{Operationalized variables}

The first variable is the foreign ownership, We follow (Chen, Zhian; Du, Jinmin; Li, Donghui; Ouyang 2003) Chen et al. (2013) to calculate foreign ownership as both dependent and independent variable from the sum of stocks owned by foreign at company itime $t$ below: Foreign ownership

Foreign $=\frac{\sum \text { stock owned by foreign }_{\mathrm{i}, \mathrm{t}}}{\sum \text { total }_{\text {shares }} \text { recorded }_{\mathrm{i}, \mathrm{t}}} * 100 \%(\mathrm{a})$

The following variables are the key performance proxy; we used some variables, e.g. return on asset $(R O A)$, return on equity (ROE). Then, we also measured the market performance of stocks by employing the dividend payout ratio (DPR), earning per shares (EPS), market-to-book (MTB), price to earnings ratio (PER) is the ratio which reflects a relative value of the firm's stock om the market (Chen, Zhian; Du, Jinmin; Li, Donghui; Ouyang 2003), and the last is Tobin's $Q$ ratio. Those variables also can be dependent and independent variables in the models. The $R O A$ is a ratio of net income divided by the total asset, ROA is commonly used for measuring the performance and efficiency like Khamis et al. (2015) and Chaganti and Damanpour (1991) who used ROA to measure the performance. According to McGuinness and Ferguson (2005). The company performance and foreign ownership up to present are affected by some factors, like return on asset (ROA), return on equity $(\mathrm{ROE})$, earning per share (EPS), market-tobook (MTB), and price to earnings ratio (PER). Mamatzakis et al. (2015), ROA is the ratio that can be a proxy for performance and efficiency. The company performance can be captured with some indicators like Tobin's $Q$, ROA, and ROE (Khamis et al. 2015). (Chen, Zhian; Du, Jinmin; Li, Donghui; Ouyang 2003) also used stock return which captures income to shareholders in the form of dividends and capital gains due to share price increases.

$$
\begin{aligned}
& \text { ROAi,t }=\frac{\text { net income after tax } i, t}{\text { Total asset } i, t}(b) \\
& \text { ROAi,t }=\text { return on asset stock-i at the time-t }
\end{aligned}
$$

The ROE is the ratio of net income after tax divided by the total equity, as like as ROA, $\mathrm{ROE}$ is used to measure the performance. The proxy for measuring the performance of the company is ROE according to Phung and Mishra (2015). Also, (Chen, Zhian; Du, Jinmin; Li, Donghui; Ouyang 2003) is one of the performance measures, it measures the efficiency which shareholders' investment.

$$
\begin{aligned}
& \text { ROEi,t }=\frac{\text { net income after tax } i, t}{\text { Total equity } i, t}(c) \\
& \text { ROEi,t }=\text { return on equity stock-i at the time-t }
\end{aligned}
$$

Then, the price to book value (PBV) is the ratio of the market price of the stock divided by the book value. According to Thomsen and Pederson (2000), this ratio can be used to measure the performance of the stock. The higher PBV reflects that the market appreciates higher the stock value rather than the book value. The other performance variables we did not state directly here, it would be explained in the further tables. 
Table 1.

Descriptive statistics

\begin{tabular}{ccccccccc}
\hline & $\mathbf{F O}_{i, t}(\%)$ & $\mathbf{R O A}_{i, t}$ & $\mathbf{R O E}_{i, t}$ & SDROA $_{i, t}$ & SDROE $_{i, t}$ & Size $_{i, t}(\mathbf{m})$ & Age $_{i, t}$ & Lev $_{i, t}$ \\
\hline Mean & 0.22 & 6.81 & 13.05 & 1.82 & 5.14 & $28,391,305$ & 34.97 & 1.51 \\
Median & 0.09 & 4.89 & 11.58 & 1.12 & 2.49 & $8,972,412$ & 32.00 & 1.05 \\
Maximum & 0.97 & 50.79 & 160.99 & 45.81 & 62.27 & $401,000,000$ & 106.00 & 14.81 \\
Minimum & 0.00 & -33.69 & -239.52 & 0.03 & 0.09 & 59,929 & 5.00 & -11.44 \\
Std. Dev. & 0.27 & 9.28 & 25.54 & 2.96 & 8.32 & $53,519,158$ & 16.80 & 2.07 \\
Skewness & 0.98 & 1.31 & -0.86 & 8.93 & 3.80 & 3.91 & 1.19 & 2.61 \\
Kurtosis & 2.64 & 7.55 & 30.13 & 117.19 & 19.58 & 20.12 & 5.42 \\
Jarque-Bera & 79.48 & 555.61 & 14874.02 & 268815.10 & 6696.82 & 7,133 & 232.43 & 6076.49 \\
Probability & 0.00 & 0.00 & 0.00 & 0.00 & 0.00 & 0.00 & 0.00 & 0.00 \\
Sum & 106 & 3290.30 & 6305.51 & 876.81 & 2484.87 & $1.37 \mathrm{E}+10$ & 16890.00 & 729.15 \\
Sum Sq. Dev. & 34.08 & 41538.60 & 314391.20 & 4223.29 & 33326.85 & $1.38 \mathrm{E}+18$ & 136004.50 & 2069.23 \\
Observations & 483 & 483 & 483 & 483 & 483 & 483 & 483 \\
\hline
\end{tabular}

Note: $\mathrm{FO}_{i, t}$ is the percentage of foreign ownership where it is counted by the number of stocks owned by the foreign investors divided by the total shares recorded on the stock itime $t$. $\mathrm{ROA}_{i, t}$ is defined by the return on asset stock itime $\mathrm{t}$, it is calculated by the natural logarithm of return on the asset the year itime $t$ divided by the return on the asset the year $t-1 . \mathrm{ROE}_{i, t}$ is defined by the return on equity of stock itime $\mathrm{t}$, it is calculated by the natural logarithm of return on equity the year itime $t$ divided by the return on equity the year $t$ 1.SDROA $i, t$ is defined by the standard deviation of return on asset stock itime $t$, it is calculated by the natural logarithm of return on the asset the year itime $t$ divided by the return on the asset the year $t$-1.Size $e_{i, t}$ is measured by the market capitalization (in million). Age ${ }_{i, t}$ is counted since the company established. leverage $e_{i, t}$ is the ratio of total debt divided by the total asset.

$\mathrm{M} / \mathrm{Bi}, \mathrm{t}=\frac{\text { market price of stock per shares } \mathrm{i}, \mathrm{t}}{\text { book value of stock per shares } \mathrm{i}, \mathrm{t}}(\mathrm{d})$

$\mathrm{M} / \mathrm{Bi}, \mathrm{t}=$ market to book ratio stock-i at the time-t

Furthermore, we also measured the risk of stock by using some risk variables. They are thestandard deviation of ROA and ROE, and Z-score. followsPhung and Mishra (2015).

\section{Control variables}

We also utilized some control variables in our models; those are selected as a control since they also have the potency to affect the performance and risk of the stock. They are size, leverage, age, and turnover. The size is the natural logarithm of market capitalization. It follows (Chen, Zhian; Du, Jinmin; Li, Donghui; Ouyang 2003) who used log transformation to account for skewness in the market capitalization distribution. Then leverage is the ratio of total debt divided by the total asset. Age is the year since the company established. The turnover is a ratio of stock trading frequency at the year $t$.

\section{An empirical model of hypotheses testing}

The model is regression analysis (ordinary least square), we used this model to examine the relationship between independent variables to the dependent variables. We also used some additional proxies to robust our testing results (with and without control models), and other robustness tests in the last. The regression analysis used Eviews 10.0. The empirical model is adopted from Liu and Hsu (2014) to test the hypotheses composed as follows:

Hypothesis 1

Yperformance $_{i, t}=\alpha+\beta_{1} X_{F_{\text {Foi }}}+\beta_{2}$ size $_{i, t}+$ $\beta_{3}$ leverage $_{i, t}+\beta_{4}$ age $_{i, t}+\beta_{5}$ turnover $_{i, t}+e$

Hypothesis 2

Yrisk $_{i, t}=\alpha+\beta_{1} X_{F_{0 i}, t}+\beta_{2}$ size $_{i, t}+\beta_{3}$ leverage $_{i, t}$ $+\beta_{4}$ age $_{i, t}+\beta_{5}$ turnover $_{i, t}+e$

Hypothesis 3

$\mathrm{Y}_{\mathrm{FO}, \mathrm{t}}=\alpha+\beta_{1}$ Xperformance $_{\mathrm{i}, \mathrm{t}}+\beta_{2}$ size $_{\mathrm{i}, \mathrm{t}}+$ $\beta_{3}$ leverage $_{i, t}+\beta_{4}$ age $_{i, t}+\beta_{5}$ turnover $_{i, t}+e$

Hypothesis 4

$Y_{\mathrm{FO}_{\mathrm{i}, \mathrm{t}}}=\alpha+\beta_{1}$ Xrisk $_{\mathrm{i}, \mathrm{t}}+\beta_{2}$ size $_{\mathrm{i}, \mathrm{t}}+\beta_{3}$ leverage $_{\mathrm{i}, \mathrm{t}}+$ $\beta_{4}$ age $_{i, t}+\beta_{5}$ turnover $_{i, t}+e$ 


\section{RESULTS AND DISCUSSION}

In this section, we present the descriptive statistic, regression analysis, and robustness tests. Table 1 depicts the descriptive statistic of data entailing the mean of foreign ownership (FO), return on asset $(R O A)$, return on equity (ROE), standard deviation of return on asset (SDROA), and standard deviation of return on equity (SDROE) as follows: FO (22\%), ROA (6.81), ROE (13.05), SDROA (1.82), size (28,391,305 million), age (34.97 years), and leverage (1.51). The other components in Table 1 are below:

Then, Table 2 explains the correlation coefficient among variables including $\mathrm{FO}$, ROA, ROE, SDROA, SDROE, size, leverage, and age. It helped to provide an earlier description of the correlation between variables before we conduct the regression analysis. This step also avoids the multicollinearity among independent variables. As presented in Table 2, no high correlation between variables, the correlation of $\mathrm{FO}$ to size is 0.23 , while the correlation of $F O$ to ROA and ROE are 0.11 and 0.11 . The others like SDROA, SDROE, leverage, and age are below than 0.09 .

On Table 3 in particular Panel A, we start to regress the foreign ownership (FO) as an independent variable to the performance as dependent variable which is measured by the return on asset (ROA) and the return on equity (ROE). In the first column, foreign ownership has a positive relationship to the ROA without including the control variables by the coefficient 4.65 at $1 \%$ level. When we included the control variables in the second column, the foreign is not significant influence to the ROA (using ordinary least squares). We did robustness test using a different method, generalized least square (EGLS with fixed effect), that accommodates the classical assumptions of Gaus Markov matters like normality, autocorrelation, multicollinearity, and heteroscedasticity due to weighing the analysis. According to Wooldridge (2012), OLS is no longer the best linear unbiased estimator in the presence of heteroscedasticity; we used theGLS estimation. It leads to weighted least squares as a means of obtaining the BLUE estimator. The test statistics from the WLS estimation are either precisely valid when the error term is in the normal distribution or asymptotically valid under nonnormality. It assumes, of course, that we have the proper model of heteroscedasticity.

The results in the Table 3 Panel $A$, the foreign ownership consistent contributes positively to the ROA. Furthermore, we conducted to analyze the relationship between foreign ownership and the return on equity. The foreign also has a positive relationship to the ROE. Nevertheless, the same result like ROA occurs when we run FO to ROE entailing the control variables. Surprisingly, when we used the EGLS-fixedeffect method, the foreign negatively affect the ROE at $1 \%$ level. Overall, foreign ownership is vital to increase the asset performance. However, it reduced the equity performance of

Table 2.

Correlation coefficient

\begin{tabular}{ccccccccc}
\hline & $\mathbf{F O}_{i, t}$ & $\mathbf{R O A}_{i, t}$ & $\mathbf{R O E}_{i, t}$ & $\mathbf{S D R O A}_{i, t}$ & $\mathbf{S D R O E}_{i, t}$ & Size $_{i, t}$ & Leverage $_{i, t}$ & Age $_{i, t}$ \\
\hline $\mathrm{FO}$ & 1.00 & & & & & & & \\
$\mathrm{ROA}$ & 0.10 & 1.00 & & & & & & \\
$\mathrm{ROE}$ & 0.11 & 0.83 & 1.00 & & & & & \\
SDROA & 0.01 & 0.14 & 0.04 & 1.00 & & & & \\
SDROE & 0.04 & 0.05 & 0.01 & 0.56 & 1.00 & & & \\
Size & 0.23 & 0.38 & 0.36 & -0.07 & -0.01 & 1.00 & & \\
Leverage & 0.01 & -0.17 & -0.07 & -0.12 & 0.05 & -0.07 & 1.00 & \\
Age & 0.08 & 0.06 & 0.12 & 0.03 & 0.03 & 0.19 & 0.10 & 1.00 \\
\hline
\end{tabular}

Note: $\mathrm{FO}_{i, \text { is }}$ the percentage of foreign ownership where it is counted by the number of stocks owned by the foreign investors divided by the total shares recorded on the stock itime $t . \mathrm{ROA}_{i, t}$ is defined by the return on asset stock itime $t$, it is calculated by the natural logarithm of return on the asset the year itime $t$ divided by the return on the asset the year $t-1 . \mathrm{ROE}_{i, t}$ is defined by the return on equity of stock itime $t$, it is calculated by the natural logarithm of return on equity the year itime $t$ divided by the return on equity the year $t-1$.SDROA $A_{i t}$ is defined by the standard deviation of return on asset stock itime $t$, it is calculated by the natural logarithm of return on the asset the year itime $t$ divided by the return on the asset the year $t-1 . \mathrm{SDROE}_{i, t}$ is defined by the standard deviation of return on equity of stock itime $\mathrm{t}$, it is calculated by the natural logarithm of return on equity in the year itime $t$ divided by the return on the asset the year $t-1$.Size $i, t$ is measured by the market capitalization (in million). Age $e_{i, t}$ is counted since the company established. leverage $e_{i, t}$ is the ratio of total debt divided by the 
Table 3.

Regression analysis of foreign ownership $x(y)$ and performance $y(x)$

\begin{tabular}{|c|c|c|c|c|c|c|}
\hline \multicolumn{7}{|c|}{ Panel A. Y = fundamental performance proxies; X = Foreign Ownership (FO) } \\
\hline & $\mathbf{R O A}_{i, t}$ & $\mathbf{R O A}_{i, t}$ & ROA (EGLS) $)_{i, t}$ & $\mathbf{R O E}_{i, t}$ & $\mathbf{R O E}_{i, t}$ & ROE (EGLS) $)_{i, t}$ \\
\hline Const. & $\begin{array}{c}5.27^{\star \star \star} \\
(0.59)\end{array}$ & $\begin{array}{l}-41.51^{\star \star \star} \\
(4.37)\end{array}$ & $\begin{array}{l}-28.82^{\star \star \star} \\
(2.22)\end{array}$ & $\begin{array}{l}10.61^{\star \star \star} \\
(2.77)\end{array}$ & $\begin{array}{l}-113.54^{\star \star \star} \\
(22.16)\end{array}$ & $\begin{array}{l}-60.44^{\star * *} \\
(9.97)\end{array}$ \\
\hline $\mathrm{FO}$ & $\begin{array}{c}4.65^{\star * *} \\
(1.72)\end{array}$ & $\begin{array}{l}2.41 \\
(1.58)\end{array}$ & $\begin{array}{l}2.09^{* * *} \\
(0.75)\end{array}$ & $\begin{array}{l}13.35^{\star} \\
(8.06)\end{array}$ & $\begin{array}{l}7.64 \\
(8.01)\end{array}$ & $\begin{array}{l}-6.51^{\star * *} \\
(0.78)\end{array}$ \\
\hline L.Size & & $\begin{array}{l}3.02^{* * *} \\
(0.27)\end{array}$ & $\begin{array}{l}2.20^{* * *} \\
(0.14)\end{array}$ & & $\begin{array}{l}7.71^{\star * *} \\
(1.37)\end{array}$ & $\begin{array}{l}9.73^{\star \star *} \\
(0.65)\end{array}$ \\
\hline Leverage & & $\begin{array}{l}-0.16 \\
(0.14)\end{array}$ & $\begin{array}{l}-0.22^{* *} \\
(0.09)\end{array}$ & & $\begin{array}{l}-1.38 \\
(0.87)\end{array}$ & $\begin{array}{l}-0.71 \\
(0.47)\end{array}$ \\
\hline Age & & $\begin{array}{l}-0.02 \\
(0.02)\end{array}$ & $\begin{array}{l}-0.02^{* *} \\
(0.01)\end{array}$ & & $\begin{array}{l}0.11 \\
(0.13)\end{array}$ & $\begin{array}{l}-2.29^{* \star *} \\
(0.11)\end{array}$ \\
\hline R-squared & 0.01 & 0.21 & 0.36 & 0.01 & 0.08 & 0.83 \\
\hline Prob. & 0.01 & 0.00 & 0.00 & 0.10 & 0.00 & 0.00 \\
\hline $\mathrm{FE}$ & No & No & Yes & No & No & Yes \\
\hline Obs. & 525 & 510 & 510 & 512 & 497 & 497 \\
\hline
\end{tabular}

Panel B. Y = Foreign Ownership (FO); $X$ = fundamental performance proxies

\begin{tabular}{|c|c|c|c|c|c|c|}
\hline & $\mathbf{F O}_{i, t}$ & $\mathbf{F O}_{i, t}$ & FO (EGLS) $)_{i, t}$ & FO (EGLS) $)_{i, t}$ & $\mathrm{FO}(\mathrm{RLS})_{i, t}$ & FO (FMOLS) $)_{i, t}$ \\
\hline \multirow{2}{*}{ Const. } & $0.20^{\star \star \star}$ & -0.10 & -0.05 & $0.22^{\star \star \star}$ & 0.03 & \\
\hline & $(0.01)$ & $(0.14)$ & $(0.10)$ & $(0.05)$ & $(0.10)$ & \\
\hline \multirow{2}{*}{ ROA } & 0.0025 & 0.001 & -0.0002 & $-0.001^{* *}$ & $-0.004^{\star \star *}$ & $-0.01^{* *}$ \\
\hline & $(0.002)$ & $(0.002)$ & $(0.001)$ & $(0.001)$ & $(0.001)$ & $(0.005)$ \\
\hline \multirow{2}{*}{ ROE } & 0.0001 & 0.0001 & 0.0002 & -0.0000001 & 0.0003 & 0.0005 \\
\hline & $(0.0003)$ & $(0.0003)$ & $(0.0001)$ & $(0.0001)$ & $(0.0002)$ & $(0.001)$ \\
\hline \multirow{2}{*}{ L.Size } & & $0.02^{\star *}$ & $0.01^{*}$ & $0.01^{* \star *}$ & $0.01^{* * *}$ & $0.08^{\star \star \star}$ \\
\hline & & $(0.01)$ & $(0.01)$ & $(0.004)$ & $(0.001)$ & $(0.03)$ \\
\hline \multirow{2}{*}{ Leverage } & & 0.002 & -0.001 & -0.001 & -0.001 & 0.01 \\
\hline & & $(0.005)$ & $(0.003)$ & $(0.001)$ & $(0.004)$ & $(0.01)$ \\
\hline \multirow{2}{*}{ Age } & & 0.001 & 0.001 & $-0.01^{* * *}$ & $-0.001^{* *}$ & $-0.03^{* * *}$ \\
\hline & & $(0.001)$ & $(0.0005)$ & $(0.001)$ & $(0.001)$ & $(0.008)$ \\
\hline R-squared & 0.01 & 0.02 & 0.02 & 0.95 & 0.01 & 0.67 \\
\hline Prob. & 0.07 & 0.04 & 0.06 & 0.00 & 0.00 & 0.00 \\
\hline FE & No & No & No & Yes & No & No \\
\hline Obs. & 512 & 497 & 497 & 497 & 497 & 346 \\
\hline
\end{tabular}

Note: $\mathrm{FO}_{i, t}$ is the percentage of foreign ownership where it is counted by the number of stocks owned by the foreign investors divided by the total shares recorded on the stock itime $t . \mathrm{ROA}_{i, t}$ is defined by the return on asset stock itime $t$, it is calculated by the natural logarithm of return on the asset the year itime $t$ divided by the return on the asset the year $t-1 . R^{2} E_{i, t}$ is defined by the return on equity of stock itime $t$, it is calculated by the natural logarithm of return on equity the year itime $t$ divided by the return on equity the year $t$-1.SDROA $i, t$ is defined by the standard deviation of return on asset stock itime $t$, it is calculated by the natural logarithm of return on the asset the year itime $t$ divided by the return on the asset the year $t-1$.Size $i, t$ is measured by the market capitalization (in million). Age $_{i, t}$ is counted since the company established. leverage $e_{i, t}$ is the ratio of total debt divided by the total asset. The regression is using ordinary least square in the first, second, fourth, and fifth columns at Panel $A$. The second, third, fifth, and sixth using EGLS. EGLS is one generalized least square methods which used cross sections weighted and also the fixed effect. Inthe Panel $B, R L S$ is a robust least square technique that could robust the statistic. FMOLS is a panel fully modified least squares

stock significantly. According to Jensen and Mckeling (1976), whereas there is a conflict between foreign and domestic investor that can make an inefficiency, it will lead to poor stock performance. Nevertheless, when the performance is good, so the foreign ownership has an important role in increasing the performance. So, hypothesis 1 is confirmed.

On the other hand, particularly Table 3 Panel $B$, it attempts to see the relationship inversely. The performance (ROA and ROE as the independent variable), then the foreign as the dependent variable. Nevertheless, the relationship is not significant with or without the control variables. When we added the fixed effect and used the RLS and FMOLS, the ROA has a negative relationship significantly to the foreign ownership (quite small), while the ROE to the foreign is not significant consistently. In short, the performance does not affect foreign ownership. Therefore, we reject the hypothesis 2. Perhaps, the Indonesian stocks are little bit unfavorable to the foreigners, or they might suppose that the Indonesian stocks are the lesser. Grinbalt and Keloharju (2000) stated the foreign investors tended to buy winner stocks and sell loser shares. Foreign investors tended to invest in shares which are well performed. The other possibility is the foreign investors are afraid to invest in Indonesia like Agarwall et al. (2009) stated that foreign investors are risk-averse than 
Table 4.

Regression analysis of foreign ownership $x(y)$ and performance $y(x)$ using different proxies

\begin{tabular}{|c|c|c|c|c|c|c|c|c|c|c|c|c|c|c|}
\hline & & & anel A. Depender & variables = & fundamental & erformance prc & xies; Inde & endent ind & cator: Foreign & wnership & FO) & & & \\
\hline & Return & Return & Return (EGLS) & EPS & EPS & EPS (EGLS) & MTB & MTB & MTB (EGLS) & PER & PER & Tobin's Q & Tobin's Q & Tobin's Q (EGLS) \\
\hline Const. & $\begin{array}{c}0.03 \\
(0.03)\end{array}$ & $\begin{array}{l}0.68^{\star \star \star} \\
(0.25)\end{array}$ & $\begin{array}{l}7.29^{\star \star \star} \\
(0.51)\end{array}$ & $\begin{array}{l}107.69^{* \star \star} \\
(24.33)\end{array}$ & $\begin{array}{l}113.84^{* \star} \\
(44.94)\end{array}$ & $\begin{array}{l}238.23^{\star \star \star} \\
(22.18)\end{array}$ & $\begin{array}{l}2.32^{* \star \star} \\
(0.78)\end{array}$ & $\begin{array}{l}-26.11^{\star \star \star} \\
(6.39)\end{array}$ & $\begin{array}{l}-25.78^{\star * \star} \\
(1.86)\end{array}$ & $\begin{array}{l}38.23^{\star \star \star} \\
(5.09)\end{array}$ & $\begin{array}{l}99.84^{* *} \\
(43.30)\end{array}$ & $\begin{array}{l}2.08^{\star \star \star *} \\
(0.72)\end{array}$ & $\begin{array}{l}-9.85^{\star \star \star} \\
(0.97)\end{array}$ & $\begin{array}{l}-6.40^{\star \star \star} \\
(0.36)\end{array}$ \\
\hline FO & $\begin{array}{l}-0.14 \\
(0.09)\end{array}$ & $\begin{array}{l}-0.08 \\
(0.25)\end{array}$ & $\begin{array}{l}-0.15^{*} \\
(0.08)\end{array}$ & $\begin{array}{l}316.21^{* * \star} \\
(71.28)\end{array}$ & $\begin{array}{l}226.41^{\star \star \star} \\
(71.30)\end{array}$ & $\begin{array}{l}-12.38 \\
(8.02)\end{array}$ & $\begin{array}{l}6.10^{* \star *} \\
(2.29)\end{array}$ & $\begin{array}{l}4.81^{* \star} \\
(2.32)\end{array}$ & $\begin{array}{l}-1.18^{* \star *} \\
(0.28)\end{array}$ & $\begin{array}{l}-19.16 \\
(14.60\end{array}$ & $\begin{array}{l}-14.52 \\
(14.92)\end{array}$ & $\begin{array}{l}-0.04 \\
(2.11)\end{array}$ & $\begin{array}{l}1.00^{\star \star *} \\
(0.35)\end{array}$ & $\begin{array}{l}-0.29^{* * *} \\
(0.06)\end{array}$ \\
\hline L.Size & & $\begin{array}{l}-0.05^{* * *} \\
(0.25)\end{array}$ & $\begin{array}{l}-0.47^{* * *} \\
(0.03)\end{array}$ & & $\begin{array}{l}0.000002^{* * *} \\
(0.00)\end{array}$ & $\begin{array}{l}0.00002^{* * *} \\
(0.00)\end{array}$ & & $\begin{array}{l}1.74^{* * *} \\
(0.40)\end{array}$ & $\begin{array}{l}2.53^{* \star \star} \\
(0.12)\end{array}$ & & $\begin{array}{l}-2.40 \\
(2.68)\end{array}$ & & $\begin{array}{l}0.67^{* * *} \\
(0.06)\end{array}$ & $\begin{array}{l}0.75^{\star \star *} \\
(0.02)\end{array}$ \\
\hline Leverage & & $\begin{array}{l}0.02^{*} \\
(0.09)\end{array}$ & $\begin{array}{l}0.02^{* *} \\
(0.01)\end{array}$ & & $\begin{array}{l}-6.64 \\
(6.25)\end{array}$ & $\begin{array}{l}1.20 \\
(1.13)\end{array}$ & & -0.41 & $\begin{array}{l}-0.62^{* \star *} \\
(0.07)\end{array}$ & & $\begin{array}{l}-4.28^{* *} \\
(1.69)\end{array}$ & & $\begin{array}{l}-0.01 \\
(0.03)\end{array}$ & $\begin{array}{l}0.00 \\
(0.01)\end{array}$ \\
\hline Age & & $\begin{array}{l}0.001 \\
(0.02)\end{array}$ & $\begin{array}{l}0.01 \\
(0.01)\end{array}$ & & $\begin{array}{l}-1.08 \\
(1.10)\end{array}$ & $\begin{array}{l}-3.14^{* * *} \\
(0.65)\end{array}$ & & 0.04 & $\begin{array}{l}-0.28^{* * *} \\
(0.02)\end{array}$ & & $\begin{array}{l}-0.50^{*} \\
(0.26)\end{array}$ & & $\begin{array}{l}0.01^{* *} \\
(0.01)\end{array}$ & $\begin{array}{l}-0.11^{* * *} \\
(0.00)\end{array}$ \\
\hline R-squared & 0.00 & 0.03 & 0.46 & 0.04 & 0.12 & 0.92 & 0.01 & 0.06 & 0.89 & 0.003 & 0.03 & 0.00 & 0.24 & 0.93 \\
\hline Prob. & 0.11 & 0.00 & 0.00 & 0.00 & 0.00 & 0.00 & 0.01 & 0.00 & 0.00 & 0.19 & 0.01 & 0.98 & 0.00 & 0.00 \\
\hline $\mathrm{FE}$ & No & No & Yes & No & No & Yes & No & No & Yes & No & No & No & No & Yes \\
\hline \multirow[t]{3}{*}{ Obs. } & 529 & 510 & 510 & 528 & 514 & 514 & 528 & 514 & 524 & 446 & 437 & 528 & 514 & 514 \\
\hline & & & Panel B. & Jependent & ariable $=$ Fore & gn Ownership & FO); Indep & ndent indi & ators: fundam & ntal perfor & nance pro & & & \\
\hline & FO & FO & FO (EGLS) & FO & FO & FO (EGLS) & FO & FO & FO (EGLS) & FO & FO & FO & FO & FO \\
\hline Const. & $\begin{array}{l}0.22^{\star \star \star} \\
(0.01)\end{array}$ & $\begin{array}{l}0.14 \\
(0.12)\end{array}$ & $\begin{array}{l}0.29 \\
(0.07)\end{array}$ & $\begin{array}{l}0.20^{\star \star \star} \\
(0.01)\end{array}$ & $\begin{array}{l}0.02 \\
(0.13)\end{array}$ & $\begin{array}{l}0.25^{\star \star \star} \\
(0.05)\end{array}$ & $\begin{array}{l}0.21^{* \star \star} \\
(0.01)\end{array}$ & $\begin{array}{l}-0.11 \\
(0.12)\end{array}$ & $\begin{array}{l}0.24^{\star \star \star} \\
(0.05)\end{array}$ & $\begin{array}{l}0.23^{* \star \star} \\
(0.01)\end{array}$ & $\begin{array}{l}-0.13 \\
(0.14)\end{array}$ & $\begin{array}{l}0.22^{* \star \star} \\
(0.01)\end{array}$ & $\begin{array}{l}0.001 \\
(0.13)\end{array}$ & $\begin{array}{l}0.18^{\star \star \star} \\
(0.05)\end{array}$ \\
\hline Return & $\begin{array}{l}-0.03 \\
(0.02)\end{array}$ & $\begin{array}{l}-0.02 \\
(0.02)\end{array}$ & $\begin{array}{l}-0.003 \\
(0.01)\end{array}$ & & & & & & & & & & & \\
\hline EPS & & & & $\begin{array}{l}0.0001^{* * *} \\
(0.00)\end{array}$ & $\begin{array}{l}0.0001^{* * *} \\
(0.00)\end{array}$ & $\begin{array}{l}0.00001 \\
(0.00)\end{array}$ & & & & & & & & \\
\hline MTB & & & & & & & $\begin{array}{l}0.002^{\star \star \star} \\
(0.008)\end{array}$ & $\begin{array}{l}0.001^{\star \star} \\
(0.0008)\end{array}$ & $\begin{array}{l}0.0002 \\
(0.0006)\end{array}$ & & & & & \\
\hline PER & & & & & & & & & & $\begin{array}{l}-0.0002 \\
(0.0001)\end{array}$ & $\begin{array}{l}-0.0001 \\
(0.0001)\end{array}$ & & & \\
\hline \multicolumn{2}{|l|}{ Tobin's Q } & & & & & & & & & & & $\begin{array}{l}-0.00001 \\
(0.0009)\end{array}$ & $\begin{array}{l}0.02^{\star *} \\
(0.01)\end{array}$ & $\begin{array}{l}-0.00002 \\
(0.001)\end{array}$ \\
\hline \multicolumn{2}{|l|}{ L.Size } & $\begin{array}{l}0.02^{* \star *} \\
(0.01)\end{array}$ & $\begin{array}{l}0.01 \\
(0.00)\end{array}$ & & $\begin{array}{l}0.01 \\
(0.01)\end{array}$ & $\begin{array}{l}0.01^{* * *} \\
(0.00)\end{array}$ & & $\begin{array}{l}0.02^{* *} \\
(0.01)\end{array}$ & $\begin{array}{l}0.01^{* * *} \\
(0.003)\end{array}$ & & $\begin{array}{l}0.02^{\star *} \\
(0.01)\end{array}$ & & $\begin{array}{l}0.01 \\
(0.01)\end{array}$ & $\begin{array}{l}0.02^{* * *} \\
(0.004)\end{array}$ \\
\hline \multicolumn{2}{|l|}{ Leverage } & $\begin{array}{l}0.002 \\
(0.00)\end{array}$ & $\begin{array}{l}0.002 \\
(0.00)\end{array}$ & & $\begin{array}{l}0.002 \\
(0.00)\end{array}$ & $\begin{array}{l}-0.0008 \\
(0.00)\end{array}$ & & $\begin{array}{l}0.002 \\
(0.03)\end{array}$ & $\begin{array}{l}-0.0008 \\
(0.001)\end{array}$ & & $\begin{array}{l}-0.01 \\
(0.001)\end{array}$ & & $\begin{array}{l}0.002 \\
(0.003)\end{array}$ & $\begin{array}{l}-0.001 \\
(0.001)\end{array}$ \\
\hline \multicolumn{2}{|l|}{ Age } & $\begin{array}{l}0.001 \\
(0.00)\end{array}$ & $\begin{array}{l}0.01 \\
(0.00)\end{array}$ & & $\begin{array}{l}0.0007 \\
(0.00)\end{array}$ & $\begin{array}{l}0.01^{* \star *} \\
(0.00)\end{array}$ & & $\begin{array}{l}0.0006 \\
(0.0006)\end{array}$ & $\begin{array}{l}-0.005^{\star * \star} \\
(0.001)\end{array}$ & & $\begin{array}{l}0.001^{* *} \\
(0.0008)\end{array}$ & & $\begin{array}{l}0.0004 \\
(0.0006)\end{array}$ & $\begin{array}{l}-0.01^{* * *} \\
(0.001)\end{array}$ \\
\hline \multirow{4}{*}{$\begin{array}{l}\text { R-squared } \\
\text { Prob. } \\
\text { Fixed effect } \\
\text { Obs. }\end{array}$} & 0.004 & 0.02 & 0.02 & 0.04 & 0.04 & 0.96 & 0.01 & 0.03 & 0.96 & 0.003 & 0.03 & 0.000001 & 0.03 & 0.96 \\
\hline & 0.11 & 0.03 & 0.03 & 0.00 & 0.0001 & 0.00 & 0.008 & 0.01 & 0.00 & 0.19 & 0.02 & 0.98 & 0.001 & 0.00 \\
\hline & No & No & Yes & No & No & Yes & No & No & Yes & No & No & No & No & Yes \\
\hline & 529 & 510 & 510 & 528 & 514 & 514 & 528 & 514 & 514 & 446 & 437 & 528 & 514 & 514 \\
\hline \multicolumn{15}{|c|}{ 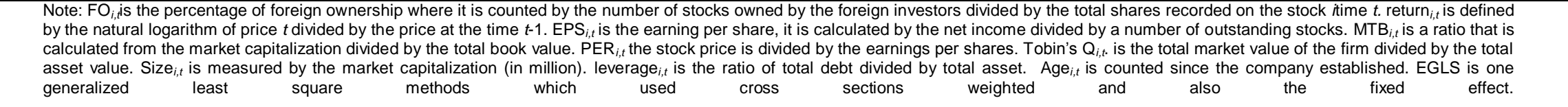 } \\
\hline
\end{tabular}


Furthermore, we reanalyze the result by utilizing the different proxies of performance that is the market performance of the stocks as presented in Table 4. We used the return, earnings per shares (EPS), market-to-book (MTB), price to earnings ratio (PER), and Tobin's $Q$. In Table 4 at Panel $A$, the independent variable is foreign ownership, and the dependent variable is the performance proxies. As presented, the FO has a negative relationship significantly return, MTB, and Tobin's $Q$ by using EGLS cross sections weighted and fixed effect. Nevertheless, the FO has a positive relationship to EPS, MTB, and Tobin's $Q$ using the ordinary least square method with and withoutthe controls except to the return (with and without control), PER (with and without control), and Tobin's $Q$ (without control).

We prefer to use EGLS as a reference, by virtue of the possible bias matter in the ordinary least square. The generalized least square accommodates it and the results are more valid. Shortly, the foreign ownership decreased the return, market-to-book, and Tobin's $Q$, but it increased the earning per shares. Hypothesis 1 is supported, albeit the impact of foreign ownership mostly negative on the performance of the stock in the market. Regarding the stock performance in the capital market, the foreign ownership may increase the conflict (agency) in the company based on the agency theory (Jensen and Mckeling, 1976), conflict from the foreign to the manager and the domestic investors, it

Table 5.

Regression analysis of foreign ownership $x(y)$ and risk y (x)

\begin{tabular}{|c|c|c|c|c|c|c|}
\hline \multicolumn{7}{|c|}{ Panel A. Y = fundamental performance proxies; X = Foreign Ownership (FO) } \\
\hline & SDROA $_{i, t}$ & SDROA $_{i, t}$ & SDROA (EGLS) ${ }_{i, t}$ & $\operatorname{SDROE}_{i, t}$ & SDROE $_{i, t}$ & SDROE (EGLS) $)_{i, t}$ \\
\hline \multirow[t]{2}{*}{ Const. } & $2.07^{* \star *}$ & 5.66 & $4.32^{\star \star \star}$ & $4.76^{\star \star \star}$ & $9.19^{\star *}$ & $7.58^{\star \star \star}$ \\
\hline & $(0.21)$ & $(1.76)$ & $(1.05)$ & $(0.47)$ & $(4.02)$ & $(2.17)$ \\
\hline \multirow[t]{2}{*}{$\mathrm{FO}_{i, t}$} & -0.06 & 0.19 & $0.27^{*}$ & 1.21 & 1.59 & 0.52 \\
\hline & $(0.62)$ & $(0.63)$ & $(0.15)$ & (1.37) & (1.43) & $(0.35)$ \\
\hline \multirow[t]{2}{*}{ L.Size $_{i, t}$} & & -0.27 & -0.06 & & -0.32 & -0.13 \\
\hline & & $(0.11)$ & $(0.07)$ & & $(0.25)$ & $(0.15)$ \\
\hline \multirow[t]{2}{*}{ Leverage $_{i, t}$} & & -0.23 & -0.04 & & 0.16 & $-0.64^{\star * *}$ \\
\hline & & $(0.06)$ & $(0.04)$ & & $(0.19)$ & $(0.17)$ \\
\hline \multirow[t]{2}{*}{$\mathrm{Age}_{i, t}$} & & 0.03 & $-0.04^{* \star *}$ & & 0.01 & 0.01 \\
\hline & & $(0.01)$ & $(0.01)$ & & (0.02) & $(0.03)$ \\
\hline R-squared & 0.00001 & 0.05 & 0.60 & 0.001 & 0.01 & 0.80 \\
\hline Prob. & 0.93 & 0.04 & 0.00 & 0.38 & 0.40 & 0.00 \\
\hline Fixed effect & No & No & No & No & No & Yes \\
\hline Obs. & 522 & 503 & 503 & 504 & 486 & 486 \\
\hline \multicolumn{7}{|c|}{ Panel B. Y = Foreign Ownership (FO); X: fundamental performance proxies } \\
\hline & $\mathbf{F O}_{i, t}$ & $\mathrm{FO}_{i, t}$ & FO (EGLS) $)_{i, t}$ & $\mathrm{FO}_{i, t}$ & $\mathrm{FO}_{i, t}$ & FO (EGLS) $)_{i, t}$ \\
\hline \multirow[t]{2}{*}{ Const. } & $0.22^{* * *}$ & -0.20 & $0.25^{\star \star *}$ & 0.22 & -0.19 & $0.21^{\star \star \star}$ \\
\hline & $(0.01)$ & $(0.13)$ & $(0.06)$ & $(0.01)$ & $(0.13)$ & $(0.05)$ \\
\hline $\mathrm{SDROA}_{i, t}$ & $\begin{array}{c}-0.002 \\
(0.003)\end{array}$ & $\begin{array}{l}0.0009 \\
(0.003)\end{array}$ & $\begin{array}{r}-0.0001 \\
(0.001)\end{array}$ & & & \\
\hline \multirow[t]{2}{*}{$\mathrm{SDROE}_{i, t}$} & & & & 0.001 & 0.002 & -0.0001 \\
\hline & & & & $(0.001)$ & $(0.00$ & $(0.0003)$ \\
\hline \multirow[t]{2}{*}{ L.Size $_{i, t}$} & & $0.02^{\star \star \star}$ & $0.01^{\star \star \star}$ & & $0.02^{\star * \star}$ & $0.01^{* *}$ \\
\hline & & $(0.01)$ & $(0.004)$ & & $(0.01)$ & $(0.004)$ \\
\hline \multirow[t]{2}{*}{ Leverage $_{i, t}$} & & 0.003 & -0.001 & & 0.003 & -0.0005 \\
\hline & & $(0.004)$ & $(0.001)$ & & $(0.01)$ & $(0.001)$ \\
\hline \multirow[t]{2}{*}{$\operatorname{Age}_{i, t}$} & & 0.001 & $-0.01^{* * *}$ & & 0.001 & $-0.004^{* * *}$ \\
\hline & & $(0.0007)$ & $(0.001)$ & & $(0.001)$ & $(0.001)$ \\
\hline R-squared & 0.0001 & 0.02 & 0.96 & 0.001 & 0.02 & 0.97 \\
\hline Prob. & 0.93 & 0.02 & 0.00 & 0.38 & 0.02 & 0.00 \\
\hline Fixed effect & No & No & Yes & No & No & Yes \\
\hline Obs. & 522 & 503 & 503 & 504 & 486 & 486 \\
\hline \multicolumn{7}{|c|}{ 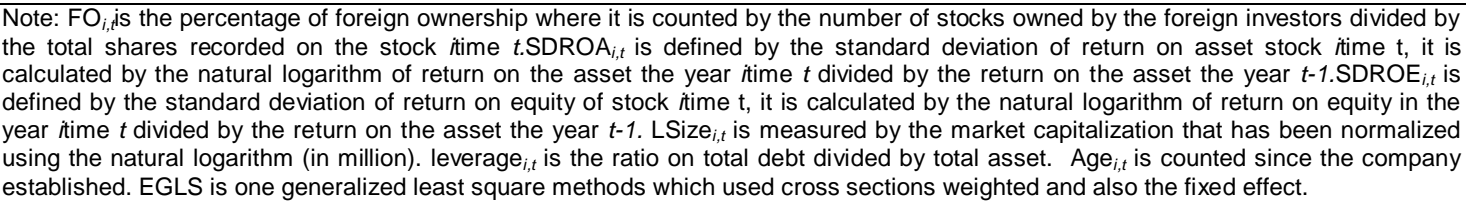 } \\
\hline
\end{tabular}


leads the poor performance. It confirmed that we support the hypothesis. In the Panel B Table 4, the independent variables are the performance proxies, and the dependent variable is the foreign ownership. By using OLS, the earning per shares, market-to-book, and the Tobin's $Q$ have the positive relationship to foreign ownership. When we compared by using EGLS method (cross section weight and fixed effect), no performanceproxies which influence the foreign ownership. Then, when we exclude the controls variable, there is also no performance proxies affect the foreign to enter except the EPS and PER. To summarize, the market performance proxies not significantly affect the percentage of foreign ownership.

Nonetheless, foreign ownership affects the market performance of the stock. It rejected that hypothesis 3 (performance has the effectof attracting the foreign). Shapiro (2006) stated the foreign investors who want to invest in another country would face some risks like currency, asymmetricliquidity information, regulation, and the different market time. So, they commonly did not invest in Indonesia. Azar (2010) added the risk that the foreign investors would face not only the stock risk but also the currency risk.

In the next step, we attempted to analyze the relationship between foreign ownership to the risk of the stock. Firstly, we used some proxies to measure the risk like the standard deviation of return on asset (SDROA) and the standard deviation of return on equity (SDROE). InTable 5 especially in Panel A, the independent variable is foreign ownership, while the dependent variable is the risk. The analysis presents that foreign ownership only affects the risk of the assetpositively significant (using EGLS), preferably to the risk of equity is not significant.

To sum up, the higher foreign ownership, the more considerable risk of the asset. It

Table 6.

Regression analysis of foreign ownership $x(y)$ and risk y (x) using different proxies

\begin{tabular}{|c|c|c|c|c|c|c|}
\hline \multicolumn{7}{|c|}{ Panel A. Dependent variables = fundamental risk proxies; Independent indicator: Foreign Ownership (FO) } \\
\hline & $\mathrm{DPR}_{i, t}$ & $\mathrm{DPR}_{i, t}$ & DPR (EGLS) $i, t$ & Z Score $_{i, t}$ & Z Score $_{i, t}$ & Z Score (EGLS) $)_{i, t}$ \\
\hline \multirow[t]{2}{*}{ Const. } & $13.49^{\star \star \star}$ & $-67.33^{* \star *}$ & $16.99^{\star \star *}$ & $2.15^{\star \star \star}$ & $-3.37^{\star * *}$ & $1.87^{* \star *}$ \\
\hline & $(1.84)$ & $(15.03)$ & (3.99) & $(0.10)$ & $(0.76)$ & $(0.47)$ \\
\hline \multirow[t]{2}{*}{$\mathrm{FO}_{i, t}$} & 5.43 & 1.96 & 0.45 & $0.52^{* *}$ & 0.25 & 0.03 \\
\hline & (5.33) & $(5.44)$ & (1.30) & $(0.28)$ & $(0.27)$ & $(0.08)$ \\
\hline \multirow[t]{2}{*}{ L.Size $_{i, t}$} & & 5.30 & 0.31 & & $0.37^{* * *}$ & $0.23^{* * *}$ \\
\hline & & $(0.93)^{\star \star \star}$ & $(0.25)$ & & $(0.05)$ & $(0.03)$ \\
\hline \multirow[t]{2}{*}{ Leverage $_{i, t}$} & & -0.13 & 0.01 & & $-0.04^{*}$ & 0.02 \\
\hline & & $(0.50)$ & $(0.08)$ & & $(0.03)$ & $(0.01)$ \\
\hline \multirow[t]{2}{*}{$\mathrm{Age}_{i, t}$} & & -0.09 & $-0.20^{*}$ & & -0.01 & $-0.09^{* * *}$ \\
\hline & & (0.09) & $(0.10)$ & & $(0.004)$ & $(0.01)$ \\
\hline R-squared & 0.001 & 0.06 & 0.62 & 0.01 & 0.13 & 0.97 \\
\hline Prob. & 0.31 & 0.00 & 0.00 & 0.07 & 0.00 & 0.00 \\
\hline Fixed effect & No & No & Yes & No & No & Yes \\
\hline Obs. & 529 & 509 & 509 & 519 & 503 & 503 \\
\hline \multicolumn{7}{|c|}{ Panel B. Dependent variable = Foreign Ownership (FO); Independent indicators: risk proxies } \\
\hline & $\mathrm{FO}_{i, t}$ & $\mathrm{FO}_{i, t}$ & $\mathrm{FO}(\mathrm{EGLS})_{i, t}$ & $\mathrm{FO}_{i, t}$ & $\mathrm{FO}_{i, t}$ & $\mathrm{FO}(\mathrm{EGLS})_{i, t}$ \\
\hline \multirow[t]{2}{*}{ Const. } & $0.22^{\star * *}$ & -0.14 & $0.25^{* * *}$ & $0.19^{\star * *}$ & -0.12 & 0.23 \\
\hline & $(0.01)$ & $(0.13)$ & $(0.05)$ & $(0.02)$ & $(0.13)$ & $(0.05)$ \\
\hline $\mathrm{DPR}_{i, t}$ & $\begin{array}{c}0.0003 \\
(0.0003)\end{array}$ & $\begin{array}{c}0.0001 \\
(0.0004)\end{array}$ & $\begin{array}{c}-0.00003 \\
(0.00009)\end{array}$ & & & \\
\hline \multirow[t]{2}{*}{ Z Score $_{i, t}$} & & & & $0.01^{*}$ & 0.01 & 0.003 \\
\hline & & & & $(0.01)$ & $(0.01)$ & $(0.003)$ \\
\hline \multirow[t]{2}{*}{ L.Size $_{i, t}$} & & & & & $0.02^{* *}$ & $0.01^{* * *}$ \\
\hline & & 0.02 & 0.01 & & $(0.01)$ & $(0.004)$ \\
\hline \multirow[t]{2}{*}{ Leverage $_{i, t}$} & & & & & 0.002 & -0.0004 \\
\hline & & 0.001 & -0.0005 & & $(0.004)$ & $(0.001)$ \\
\hline \multirow[t]{2}{*}{$\mathrm{Age}_{i, t}$} & & & & & 0.001 & $-0.005^{* * *}$ \\
\hline & & 0.0008 & -0.01 & & $(0.001)$ & $(0.001)$ \\
\hline R-squared & 0.001 & 0.02 & 0.96 & 0.01 & 0.02 & 0.96 \\
\hline Prob. & 0.00 & 0.04 & 0.00 & 0.07 & 0.04 & 0.00 \\
\hline Fixed effect & No & No & Yes & No & No & Yes \\
\hline Obs. & 529 & 509 & 509 & 519 & 503 & 503 \\
\hline
\end{tabular}

Note: $\mathrm{DPR}_{i, t}$ is the dividend payout ratio, it is calculated by the percentage of dividend paid from the net income. Z Score $e_{i, t}$ is the bankruptcy indicators from Altman. $\mathrm{FO}_{i, \text { is }}$ the percentage of foreign ownership where it is counted by the number of stocks owned by the foreign investors divided by the total shares recorded on the stock itime $t$. LSize $_{i, t}$ is measured by the market capitalization that has been normalized using the natural logarithm (in million). leverage $e_{i, t}$ is the ratio on total debt divided by total asset. Age $e_{i, t}$ is counted since the company established. EGLS is one generalized least square methods which used cross sections weighted and also the fixed effect 
confirmed the hypothesis 2 where foreign ownership affects the risk of the stock. Wang (2007) proved that foreign ownership negativelyaffects the company because the stocks owned by the foreign not evidently the risk would be lower. Instead, the risk would be more significant. In the agency theory (Jensen and Mckeling, 1976), the agency problem and conflict between foreign shareholders and manager may arise. That conflict leads the inefficiency and influences the policy or decision taking in the corporation. Overall, those lead to the company performance becoming worse. Then on the Panel $\mathrm{B}$, both SDROA and SDROE do not affect the percentage of foreign ownership. So, the risk of asset and equity do not affect significantly to the foreign ownership. It rejected hypothesis 4 where the risk effects the foreign ownership. Some found that there is no interaction between foreign ownership to the stock's performance and risk. It is explained by the company's decision which is mostly decided by the majority shareholders, in this case, the foreign owners as the minority shareholders. Therefore, the foreign has no role in that decision (Bekaert and Harvey, 1997; De Santis and Imrohoroglu, 1994; Kim and Singal, 2000). The assumption that the higher or lower risk affect the foreign to own or avoid that stock is not occurred.

To confirm our result, we reanalyzed the relationship between foreign ownership and Our study limits the samples only in Indonesia and excludes the financial company. Furthermore, for future research, we recommend enhancing the robustness tests like adding the percentile, splitting samples into high and low foreign ownership, and improving the alternative risk measurements. We also recommend enlarging the year of observations, in particular, until the crisis period. Therefore, we could obtain the different role of foreign ownership to the performance and risk during the crisis. The big data analysis like enlarging the samples across the countries, so we could attain the global role of the foreign. It is difficult, but it would contribute significant impact to the world.

the risk of stock using different proxies. We utilized the dividend payout ratio (DPR) and the Z Score from Altzman. In Table 6, the Panel A depicts that the foreign ownership does not influence significantly to the risk proxies. It rejected the hypothesis 2 where FO effects performance and risk is not significant, Albeit, it affects significantly at $5 \%$ level to the
Z score. Nevertheless, we exclude the control variables and use the OLS method. Therefore, it may contain bias matter. We firmly believe that the GLS results are more valid. Some found that there is no interaction between foreign ownership to the stock's performance and risk. It explained that the company's decision is largely decided by the majority shareholders, in this case, the foreign owners as the minority shareholders. Therefore, the foreign has no role in that decision (Bekaert and Harvey, 1997; De Santis and Imrohoroglu, 1994; Kim and Singal, 2000).

Then, on the Panel B. Overall, the results are like the Panel A that there is no effect of the risk toward the foreign ownership percentage. We rejected the hypothesis 4 where the risk effects the foreign ownership. Bekaert and Harvey (1997), De Santis and Imrohoroglu (1994), Kim and Singal (2000) stated that there is no interaction between foreign ownership andstock risk.

\section{CONCLUSION}

We found that foreign ownership contributes positively to some performance indicators, while they also contribute positively to the foreign without control variables. This relationship would be lower when we use some control variables. On the other hand, the relationship between foreign and risk are mostly insignificant, only foreign to z score are significant. The risk also not influences the foreign ownership of the stock.

In conclusion, foreign ownership has an essential role to improve the performance of the stock and vice versa. Therefore, we should not limit foreign ownership in Indonesia. Due to the benefits like the improvement of performance from its role. The foreign ownership contributes to the company like the better governance, control, technology transfer. Therefore, the performance would increase. The inverse relationship such the performance affects the foreign to enter does not occur.

\section{REFERENCES}

Aebi, V., G. Sebato., \& M. Schmid.(2011). Risk management, corporate governance, and bank performance.Journal of Banking and Finance. 36. 3213-3226.

Agarwal, S., S. Farcloth., C. Liu., and S.G. Rhee.(2009). Why does foreign investor underperform domestic investor in trading 
activities? Evidence from Indonesia.Journal of Financial Market. 12. 32-53.

Alin, N. L. (2011). Foreign investment influence on ownership and control in Japanese firms.Working Paper.Faculty of Business.University Cluj-Napoca, Japan.610-615.

Ang, J., R. Cole., and D. Lawson.(2010). The role of the owner in capital structure decisions: an analysis of single owner corporations. The Journal of Entrepreneurial Finance. 14: 1-36.

Arfaoui, M., and A. B. Rejeb.(2015). Return dynamics and volatility spillovers between forex and the stock market in Mena countries: What to remember for portfolio choice. International Journal of Management and Economics. Vol. 46.72100.

Azar, S. A. (2010). Value at risk models of the US stock market for US and foreign investors. International Review of Applied Financial Issues and Economics.Vol. 2.665686.

Bachrach, B., and D. Galai.(1979). Therisk return relationship and stock prices. The Journal of Financial and Quantitative Analysis.Vol. 14.421-441.

Becht, M., Bolton, P., Roell, A., (2003).Corporate governance and control. In: Constantinides, G. M., Harris, M., Stulz, R. M. (Eds.), Handbook of the Economics of Finance.Vol. 21 of Handbooks in Economics. Elsevier, Ch. 1, pp. 1-109.

Bekaert, G., and C. Harvey.(1997). Emerging equity market volatility. Journal of Financial Economics.Vol. 43.29-78.

Chaganti, R., and F. Damanpour. (1991). Institutional ownership, capital structure, and firm performance. Strategic Management Journal. 12: 479-491.

Chen, Z., J. Du., D. Li., and R. Ouyang. (2011). Does foreign institutional ownership increase return volatility? Evidence from China.Journal of Banking and Finance.Vol. 37.660-669.

De Santis, G., and S. Imrohoroglu.(1994). Stock return and volatility in emerging financial markets.Discussion Paper No. 93.University of Southern California.

Di Maggio, J. P., and W. W. Powell.(1983). The iron cage revisited: Instituional isomorphism and collective rationality in organizational fields. American Sociological Review. 48: 147-160.

Doidge, C., G. A. Karolyi., and R. M. Stulz.(2004). Why are foreign firms that list in the U.S. worth more? Journal of Financial Economics. Vol. 71.205-238.

Elliot, R. J. R., and Y. Zhou.(2015). Co-location and spatial wage spillovers in China: the role of foreign ownership and trade. WorldDev.Vol. 66.629-644.

Fama, E., 1970. Efficient Capital Markets: A Review of Theory and Empirical Work. Journal of Finance. 25(2)

Fama, E., and M.C. Jensen.(1983). Separation of ownership and control.Journal of Law and Economics. 26.

Fan, J. P. H., and T. J. Wong.(2002). Corporate ownership structure and the informativeness of accounting earnings in East Asia. Journal of Accounting and Economics.Vol. 33.401425.

Fuentelsaz, L., J. Gomez., E. Martinez., and Y. Polo.(2000). Remuneration policies in the marketing area: Behaviouralvs performance measures. Journal of Marketing Management. 16: 937-957.

Galais, D. and R.W. Masulis.(1976). The Option Pricing Model and the Risk Factor of Stock. Journal of Financial Economics. 1(2): 53-82.

Gomes, B. C. (1989). Ownership structures of foreign subsidiaries: Theory and Evidence. Journal of Economic Behavior and Organization. 11: 1-25.

Grinbalt, M., and M. Keloharju. (2000). The investment behavior and performance of various investor types: A study of Finland's unique data set. Journal of Financial Economics. Vol. 55.43-67.

Hennart, J. F. (1988). A transaction costs theory of equity joint ventures. Strategic Management Journal. 9: 361-374.

Jensen, M., and W. Meckling.(1976). Theory of the firm: managerial behavior, agency costs, and ownership structure. Journal of Financial Economics.3: 305-360.

Jensen, M. (1986).Agency Costs of Free Cash Flow, Corporate Finance, and Takeovers.American Economic Review, Vol. 76, No. 2, pp. 323-329.

Jiang, L., and J. B. Kim.(2004). Foreign equity ownership and information assymetry: Evidence from Japan. Journal of International Financial Management and Accounting. Vol. 15.184-213.

Jin, L., and S. C. Myers.(2006). R2 around the world: New theory and new tests. Journal of Financial Economics. Vol. 79.257-292. 
Kahneman, D., and A. Tversky.(1973). On the psychology of prediction. Psychological Review. 80 (4): 237-251.

Khamis, R., A. M. Hamdan., and W. Elali.(2015). The relationship between ownership structure dimensions and corporate performance: Evidence from Bahrain. Australian Accounting Business and Finance Journal. 9(4): 38-56

Kim, E. H., and V. Singal.(2000). Stock market openings: Experience of emerging economies. Journal of Business.Vol. 7.2566.

Kurniawati, I., and P. T. Komalasari. 2014. Pengaruhkepemilikannegaradanasingterhad ap corporate risk taking. JurnalManajemenTeoridanTerapan. 2: 100115.

Kwon, T. H., S. C. Bae., and J. C. Chung.(2005). Do foreign investors price foreign exchange risk differently. The Journal of Financial Research.Vol. 28.555-573.

Li, D., Q. N. Nguyen., P.K. Pham., and S. X. Wei. 2011. Large foreign ownership and firm level stock return volatility in emerging markets. Journal of Financial and Quantitative Analysis.Vol. 46. pp. 11231155.

Liu, W. C., and C. M. Hsu.(2014). Profit performance of financial holding companies: Evidence from Taiwan. Emerging Markets Finance. 50: 190-200.

Mamatzakis, E., A. N. Kalyvas., and J. Piesse.(2013). Does regulation in credit, labour, and business matter for bank performance in the EU-10 economies? International Journal of The Economics and Business. 20: 341-385.

Merton, R. C. (1987). A simple model of capital market equilibrium with incomplete information.Journal of Finance.Vol. 42.483510.

Modigliani, F., and M, Miller.(1958). The Cost of Capital, Corporation Finance, and the Theory of Investment", American Economic Review, Vol. 48, pp. 655-669.

Mintzberg, H. (1978). Patterns in strategy formation.Manage Science. 24 (9): 934948.

Olcott, G. (2009). Conflict and Change: Foreign Ownership and The Japanese Firm. Cambridge University Press. UK.

Pambudi, D. and R. Smyth.(2009). Making Indonesia more attractive to foreign investors: A computable general equilibrium analysis of reducing the premium in Central Java. RURDS. Vol 20: 226-240.
Phung, D. N., and A. V. Mishra.(2015). Ownership structure and firm performance: Evidence from Vietnamese listed firms. Australian Economic Papers.63-98.

Ricci, L. A., and F. Trionfetti.(2012). Productivity, networks, and export performance: Evidence from a cross-country firm Dataset. Review of International Economics. 20(3): 532-562.

Schwert, G. W. (1989). Why does stock market volatility change over time? The Journal of Finance.Vol. 24.No. 5.1115-1153.

Shapiro, I. (2006). Extending the Framework of Inquiry: Theories of Change in Conflict.Berghof Handbook, (5).

Shleifer, A., and Vishny, R. (1997).A survey of corporate governance.Journal of Finance. 42: 737-783.

Thomsen, S. and Pedersen, T. (2000).Ownership Structure and Economic Performance in the Largest European Companies.Strategic Management Journal. vol. 21, pp. 689-705.

Utama, C. A., and H. Musa.(2011). The causality between corporate governance practice and bank performance: Empirical evidence

from Indonesia. Gadjahmada International Journal of Business. 13: 227-247.

Vo, X. V. (2015). Foreign ownership and stock return volatility-evidence from Vietnam. Journal of Financial Management.Vol. 30.101-109.

Wang, J. (2007). Foreign ownership and volatility dynamics of Indonesia stocks. Asia Pacific Financial Markets. Vol. 14.201-210.

Williamson, O. E. (1981). The economics of organizations: The transaction cost approach. American Journal of Sociology. 87: 548-577. 